\section{THE OCEANOGRAPHY SOCIETY}

P.O. Box 1931

Rockville, MD 20849-1931 USA

t: (1) 301-251-7708; f: (1) 301-251-7709

www.tos.org

OFFICERS

H. Lawrence Clark, President

TBA, President-Elect

Eric Hartwig, Past-President

Melbourne G. Briscoe, Secretary

Susan Banahan, Treasurer

\section{COUNCILLORS}

\author{
Vernon Asper \\ James Ammerman \\ Curtiss O. Davis \\ Van Holliday \\ Lynne Talley \\ TBA
}

\section{EXECUTIVE DIRECTOR}

Jennifer Ramarui info@tos.org

\section{SPONSORS}

Fugro GEOS, Inc. www.geos.com

Martin \& Riener Technical Services www.martinandriener.com

Ober, Kaler, Grimes \& Shriver www.ober.com

RD Instruments www.rdinstruments.com

Sea-Bird Electronics, Inc. www.seabird.com

Sippican, Inc. www.sippican.com

\section{The Value of Writing Clearly}

As an undergraduate geology student at Cornell University in the late 1970s, I had no idea that writing would become an integral part of my scientific career. I didn't like to write, and figured that as a scientist, I wouldn't need to put pen to paper very often. I took only the mandatory minimum number of writing courses and was more concerned with math and science than improving my writing skills. Little did I know that as my career progressed, I would need to write more and more- and then some more. Had I understood the significance to a scientist of crafting clear prose, perhaps I would have gritted my teeth and struggled through an expository writing course or two. Now, when I talk to students about my career and answer their inevitable questions about what subjects they should study to become a scientist, they are often stunned that writing classes are high on my recommended list.

Putting together an issue of this magazine inevitably prompts thoughts about the importance of writing clearly, especially when trying to communicate to a broad audience. The rules, as Mark Twain once wrote, are obvious: "avoid slovenliness of form," "use the right word, not its second cousin" and "eschew surplusage." But for many of us, translating the results of our exciting research from technical language into prose that non-experts can understand and appreciate can be a daunting and burdensome prospect. Ultimately, however, devoting the time and effort to translating our work for a broader audience is essential to building support for our work. The non-expert we are trying to reach may simply be a colleague down the hall who studies the deep Earth rather than the deep ocean. Or, the reader may be a scientist in a different field who may collaborate with you on a multidisciplinary project. Away from universities, another reader may be a senior staffer on a congressional science committee who studied history in college, but helps make decisions about the allocation of billions of dollars of science funding. Whomever your words are directed to, writing clearly for non-technical publications makes you a more effective advocate for oceanography and for your specialty.

One last thought. While clear writing is essential to effective communication, by itself it isn't necessarily sufficient. In an age where more and more members of our audience were raised staring not just at television but also at video-game consoles and flat-screen computer monitors, visual presentation counts for a lot. There's a good reason why one professor has made a small fortune writing books and teaching seminars on the visual display of quantitative information. Good-quality graphics are essential for conveying ideas, and often are the first or only things someone will look at when flipping through a magazine or journal. Remember to take high-resolution photos of your lab, special equipment, or field work, preferably with people in them. Use color wherever possible in your figures. Make sure the font size is readable when reduced to size for the published document. And, of course, write a good figure caption.

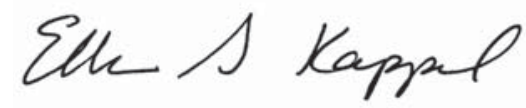

ELLEN S. KAPPEL, EDITOR 